\title{
Comparative Study Of Open Versus Laparoscopic Appendicectomy
}

\author{
Dr. Sudheer Moodadla ${ }^{1}$, Dr.J. Ravinder Naik ${ }^{2}$ \\ ${ }^{1}$ Senior resident in the Department of general surgery Konaseema institute of medical sciences Amalapuram, \\ Andhra Pradesh. \\ ${ }^{2}$ Assistant Professor in the Department of general surgery Konaseema institute of medical sciences \\ amalapuram
}

\begin{abstract}
Back Ground-Appendicitis is the common surgical emergency in the world. in order to reduce pain, infection, hospital stay and excellent cosmetic end result patients are preferring laparoscopic appendicectomy. The aim of the present study is comparative analysis between open appendicectomy and laparoscopic appendicectomy.

Methods-This study was done in Mahatma Gandhi Memorial Hospital warangal between October 2009 to October 2011 over 126 patients.

Results-out of 126 patients, 60 patients underwent open appendicectomy with 57:43 male female ratio, 66 patients underwent laparoscopic appendicectomy with 39:61 male female ratio. there no much variation in blood loss and adjacent organ injury but better results are appeared in pain, infection, duration of hospital stay, excellent cosmetic end result and use of antibiotis.
\end{abstract}

Keywords: open appendicectomy, laparoscopic appendicectomy.

\section{Introduction}

Appendicitis is the common surgical emergency in the world. It can occur in any age, though it is rare under the age 5 years. The treatment is straight forward in most of the cases and depends upon the stage of the disease. In early appendicitis, appendicectomy is the treatment of choice. It can be done by open or laparoscopic approach. The greatest contributor to the advancement in the treatment of appendicitis is Charles Mc Burney. In 1889, he published his landmark paper in the New York medical journal describing the indications for early laparotomy for the treatment of appendicitis. In this paper he described Mc Burney's point of maximum tenderness. ${ }^{1}$ Mc Burney subsequently published a paper 1894 describing the incision that bears his name. However, Mc Burney later credited Mc Arthur with first describing this incision. ${ }^{2}$ Attempts at minimally invasive therapy for afflictions of the gastrointestinal tract date back to the time of Hippocrates, who described non-invasive remedies for conditions such as intestinal obstruction, rectal prolapse, and haemorrhoids. ${ }^{3}$ Hippocrates also detailed the use of d speculum, or primitive anoscope, for examining haemorrhoids. Early endoscopists were hampered by the lack of a satisfactory light source. Thus, until the nineteenth century, physicians relied on sunlight reflected by mirrors or focused through flasks of water. ${ }^{4}$ In the early 1800 s, physicians began using candles or paraffin lamps for illumination; however, the idea of "a magic lantern into the human body" was for the most part scorned and ridiculed. ${ }^{5}$ The first experimental laparoscopy was performed in Berlin in 1901 by the German surgeon Georg Kelling, who used a cystoscope to peer into the abdomen of a dog after first insufflating it with air. ${ }^{6}$ Kelling was an early advocate of the ability of minimally invasive surgery to avoid unnecessary laparotomy and decrease hospital stays. The first human laparoscopy was performed in Sweden by Jacobeus in 1910 to investigate ascites. Diagnostic laparoscopy enjoyed some popularity in the early twentieth century, but early laparoscopists were limited by a lack of technology. ${ }^{7}$

Minimal invasive surgery had a considerable impact on common surgical techniques and has almost replaced established operative procedures such as cholecystectomy. However, the laparoscopic approach for the treatment of acute appendicitis is now-a-days getting popular. The Main advantages of the laparoscope in abdominal surgery are related to the avoidance of laparotomy wound. In most of the patients, the wound required for an open appendicectomy is not much larger than the wound for laparoscopic appendicectomy and thus the advantages of the laparoscopic appendicectomy is not obvious. The role of laparoscopic appendicectomy remains controversial as many researchers have suggested that over all morbidity is primarily a function of the degree of the appendicitis rather than the operative approach. Though several independent studies and Meta analysis of those studies have been done but the final word has not been said as yet.In 
cholecystitis, the laparoscopic approach has emerged as that clear gold standard. But, in appendicectomy different schools of thought exist regarding the method to be followed, since the protocols are still in their nascent state of standardization.

The objective of the study is therefore, it clears some of the issues stake in the Indian context.Elective surgery for the gastrointestinal tract was initiated by intrepid individuals whose talents reflected courage, manual dexterity, and digital celebrity. The advent of general anaesthesia, muscle relaxants, and antibiotics facilitated the introduction of more complex procedures and allowed a safe outcome for the patient. In almost a century of gastrointestinal surgery, few advances can compare to the revolution engendered by the advent of minimally invasive surgery. The interface of creative surgeons and the science of biotechnology have given rise to a novel consideration of hoary techniques and dogma. With the introduction of laparoscopic surgery has come the recognition of both advantages and difficulties. The benefits conferred on patients by less invasive procedures, decreased pain, and shorter recovery have to be weighed against over enthusiasm of application and the problems created by a lack of familiarity with new techniques and instruments. Nevertheless, the introduction of novel technology in a field almost synonymous with tradition has provided a unique opportunity to re-evaluate current therapeutic strategies and options.

The introduction and acceptance of laparoscopic surgery for gastrointestinal disease will undergo a number of phases. In the first, the introduction and application of new technology to perform old procedures will be evaluated. The learning curve of surgeons and the selection of patients are the primary considerations in this phase. Thereafter, consideration will be given to the application of alternative technologies not previously considered in surgery but thought of more as part of the industrial and technological complex. In this context, robotic surgical components, self-propelling devices, memory metals, and implanted miniature visual instruments are examples. The final phase will be the evolution of a generation of surgeons capable of developing therapeutic strategies radically different from those implemented by the first wave of laparoscopic surgeons, who used relatively simple and crude instrumentation. In the last phase, the ultimate goal will be the interface of the problem-solving powers of a medical mind with the manometer precision of a robotic instrument. Thus, there already are prototype operating devices with which long-range telemetric control of surgical robotic instrumentation is possible. Although this may seem exotic, technology of this sort has already been tested, patented, and employed in the aerospace and military programs. The resources and technology currently used to explore outer space might be better utilized resolving the problems of inner space as exemplified by the peritoneal cavity. Here we try to provide an overview of the current status of laparoscopic surgery, as it is applied to the management of conditions of the gastrointestinal tract that are considered to require surgical intervention. In brief, it documents the techniques and balances the applications against potential advantages and disadvantages. In essence, this overview proposes to shine a light on a surgical technique which has languished too long in the dark.

\section{Aim Of The Study}

The aim of the present work is to do a comparative study between Open appendicectomy and laparoscopic appendicectomy comparing the

Following aspects.

1. The time taken for surgery

2. Blood loss during surgery

3. Antibiotic prophylaxis

4. Usage of Analgesics

5. Duration of hospital stay

6. Complications in each type of surgery

7. Time taken to resume normal activity

8. Cost effectiveness of each type of surgery

9. Patient satisfaction and cosmetic result

\section{Materials And Methods}

The study subjects of this dissertation consist of 126 Patients who have undergone Appendicectomy at the Mahatma Gandhi Memorial Hospital, Warangal. 60 Patients had undergone Appendicectomy by the conventional open method and the remaining 66 patients underwent surgery by the laparoscopic method.All patients had come to Mahatma Gandhi Memorial Hospital between October, 2009 to October, 2011 with abdominal pain and with clinical features simulating acute appendicitis. The patients preoperative diagnosis had to be firm enough so that the surgeon would have done a right lower quadrant incision open Appendicectomy in the absence of laparoscopic technology. Patients who were scheduled for interval Appendicectomy was also included. All patients who presented with an appendicular mass and / or features generalized peritonitis were excluded. Once a case fit this criterion, depending on the patient's option, either open or a laparoscopic surgery 
was performed. Either the technique for Appendicectomy, open or laparoscopic, was left entirely to the surgeon's discretion. There was no specifically defined criterion for hospital discharge after Appendicectomy. This too was left to the discretion of the surgeon.

Data was collected on a program basis; clinical examination preoperative findings as well as postoperative recovery and follow up were all done by the respective units. In all possible cases, the surgery was done by an assistant professor and / or the Consulting Surgeon. For this study, Patient's age, sex, race, height, weight, history of previous abdominal surgery, concomitant illness, chronic medication usage, and ASA class (American Society of Anaesthesiologists risk classification) were recorded. Preoperative fever, leucocytosis, right lower quadrant pain, right lower quadrant tenderness, nausea, vomiting and anorexia were recorded. The duration of preoperative symptoms, final pathologic findings (either normal appendix, acute appendicitis, or perforated appendicitis), how the stump of the appendix was technically handled, operating time (time from initial incision to closure), complications, duration of postoperative intramuscular (IM) or intravenous (IV) analgesic Administration, time until resumption of regular diet, and length of Postoperative hospital stay was recorded.Time until return to work or normal activities was determined by examination of the postoperative outpatient medical records and by a 1 month postoperative follow-up interview. In the 1 month postoperative interview, patients were also asked to grade their perception to the cosmetic result on a scale of one to five (One being the worst and five being the best).

\section{Statistical Analysis:}

Qualitative data was summarized in terms of-percentage and the quantitative data was summarized through mean values. The standard deviation was also computed to measure the variability.

Results in the two groups were compared using appropriate statistical techniques. The difference in percentage was statistically assessed using Chi-square test / Fisher's exact test. Statistical significance between mean values was analyzed employing t-test (independent). A P-value of $<0.05$ was considered as statistically significant result.

\section{Results And Discussion}

In the present series, the patients who presented with acute symptoms between the months of October 2009 and October 2011, pre-operatively diagnosed to have acute appendicitis, admitted and operated by the surgical unit S-III were studied.

\section{Hospital Incidence Of Acute Appendicitis:}

The total number of patients admitted by various surgical units during the study period was 580 , of which as many as 126 cases were admitted and operated at the surgical unit S-III. (Table-1)

Hence, appendicitis has a hospital incidence of $0.6 \%$ of all hospital admissions and $4.5 \%$ of all general surgical admissions.

\section{Patient Demographics:}

The results of the analysis of data on 60 patients who underwent open Appendicectomy and another of 66 patients, who were operated laparoscopically are described in this selection.

\section{Age and Sex Distribution:}

Thirty four (57\%) of the patients of open Appendicectomy and twenty six (39\%) of laparoscopic Appendicectomy were males. The mean age of the Patients in the two groups were 28 and 27 years, respectively. The details are given in (Table 2). Both the groups were similar with respect to their Age and sex distribution.

\section{Presenting complaints and past history:}

Table 3 gives the details on presenting complaints. All the patients complained of abdominal pain in both the groups. The other complaints were vomiting, fever and loss of appetite. Descriptions of past history of the patients like diabetes mellitus, heart disease, previous episodes of similar pain are detailed in (Table 4).

Habits:

Both the groups were similar with respect to percentage of patients consuming alcohol. $13 \%$ of the patients who were on open group and 3\% on the laparoscopic group were smokers. About one fifth of the patients were vegetarian in both the group. (Table 5)

\section{Systemic examination:}

The findings of systemic examination of the patients in the two groups in terms of build and nutrition, anaemia, lymphadenopathy, CVS \& RS are given in Table 6. Both the groups were similar with respect to these parameters.

Local Examination: All the patients in both the groups had right iliac fossa tenderness (Table 7)

Physical Examination:

The two groups were similar with respect to their mean blood pressure, pulse rate and temperature (Table 8) 


\section{Ultrasound:}

All patients in the study except one in the open Appendicectomy group had normal results for abdominal ultrasound (Table 9)

\section{ASA Status:}

The distribution of patients according to their ASA scores in given (Table 10). It may be noted that the median score was 1 for both the groups.

\section{Position of the Appendix:}

For most of the patients (95\%) of the open Appendicectomy group and the entir laparoscopic group the position of the appendix was retrocecal (Table 11). Remarks: It can be inferred that the 60 patients who underwent open Appendicectomy and 66 patients who underwent laparoscopic Appendicectomy had similar baseline characterization from the results given above in Table 1 to 11, The result in the procedure performed on both the groups are given below.

\section{Result of the Appendicectomy:}

The blood loss was below 50ml in 93\% of the patients who underwent open Appendicectomy (Table 12) and $98 \%$ among those who underwent laparoscopic $(\mathrm{P}=0.2)$. There was no instance of adjacent organ injury in the open Appendicectomy procedure and in the laparoscopic group one had injury. The duration of laparoscopic procedure was 73 mins as Compared to 64 mins for the open procedure. The difference was not statistically significant $(\mathrm{P}=0.07)$. Laparoscopic Appendicectomy was of longer duration $73+26$ mins. Than open Appendicectomy $64+30$ mins. Even though this did not turn out to be statistically significant, when theatre charges are levied by the hour and may be in future by the minute. This difference might turn out to be costly.

\section{Ability to tackle other pathology:}

The advantage of laparoscopic surgery is best illustrated when we are able to tackle other pathology without extending the incision which would not be possible in the open method. We had 3 cases in lap method where other pathology was tackled.

1) Ectopic gestation - left fallopian tube

2) Bi-lateral ovarian cyst

3) Twisted ovarian cyst

All the three conditions were successfully tackled with laparoscopy. Negative appendicectomy was similar in both the groups to the mild increase in the laparoscopy group. This difference was not statistically significant (Table 13).

\section{Wound infection and medication:}

There was a significant difference $(\mathrm{P}=0.02)$ in the wound infection rate which was around $8 \%$ in the open group while none of the patients in the laparoscopic group. This can be seen in table 15.Voveron was the analgesic of choice and we found no significant difference in its usage in both the groups. Even though, we did not find a difference in the total days of usage of antibiotics. But, we found that the number of days of parenteral usage of antibiotics to be more in the open appendicectomy group.

\section{Post op recovery:}

Oral feeds were resumed on an average in about one day in lap surgery, while it took about $1 \frac{1 / 2}{2}$ days in open surgery. But, whether this confers any significant benefit to the patient remains to be same.

\section{Duration of hospital stay:}

Duration of hospital stay was one day more in open surgery than in laparoscopic surgery. This difference was statistically significant

\section{Return to normal activity:}

Most importantly, all the patients who underwent laparoscopic surgery were able to return to normal activity, on an average, 5 days earlier than patients who underwent open surgery. $(\mathrm{P}=0.001)$.

\section{Cosmesis}

$89 \%$ of the patients undergoing laparoscopic Appendicectomy felt that they had an excellent cosmetic end result while only $2 \%$ of open group felt the same. In our hospital the patients decided whether to undergo laparoscopy or open surgery and this is bound to have bias in their perception about the cosmesis achieved. Only $57 \%$ of the patients perceived that they had an acceptable scar in the open group.

\section{Conclusions}

In analyzing the various data we find that laparoscopic appendicectomy is similar to open appendicectomy in the parameters like blood loss, adjacent organ injury. Laparoscopic appendicectomy was better than open appendicectomy with respect to pain, wound infection, tackling co-existing pathology, duration 
of hospital stay, earlier return to normal activity, excellent cosmetic end result, lesser use of antibiotics, and earlier resumption of oral feeds.All the above mentioned advantages are at the cost of slightly increased duration of surgery and higher overall cost (which is not applicable in our study i.e. government sector). All available information indicates that laparoscopic appendicectomy has superior results and will become the standard of care.

\section{Bibliography}

[1]. Mc Burney C: Experience with early operative interference in cases of disease of the vermiform appendix. Ny state med J 50: 676; 1889.

[2]. Mc Burney C; The incision made in the abdominal wall in cases of appendicitis; Ann surg 20: 38,1894

[3]. Adams F (trans.): The Genuine Works of Hippocrates. London, Sydenham Society, 1849, pp. 820-821.

[4]. Gunning JE, Rosenzweig BA: Evolution of endoscopic surgery, in White RA, Klein SR (eds.): Endoscopic Surgery. Boston, Mosby Year Book, 1991, pp 1-9.

[5]. Berci G: History of endoscopy, in Berci G (ed): Endoscopy. New York, Appleton-Century-Crofts, 1976, pp xix - xxiii.

[6]. Kelling G: Zur Colioskopie. Archi Klin Chir 126: 226-228, 1923.

[7]. Philipi Cj, Fitzgiboons Rj, Salerno GM: Historical review: Diagnostic laparoscopy to laparoscopy cholecystectomy and beyond, in Zucker KA (ed): Surgical Laparoscopy. St. Louis, Quality Medical Publishing, 1991, pp 3-21.

TAB-1 No. of cases admitted in the hospital

\begin{tabular}{|c|c|c|c|c|}
\hline & \multicolumn{3}{|c|}{ No. of cases admitted } \\
\cline { 2 - 5 } & $\begin{array}{c}01-10-2009 \text { to } \\
31-12-2009\end{array}$ & $\begin{array}{c}01-01-2010 \text { to } \\
31-12-2010\end{array}$ & $\begin{array}{c}01-2011 \text { to } \\
30-10-2011\end{array}$ & Total \\
\hline $\begin{array}{c}\text { Total Hospital } \\
\text { admissions }\end{array}$ & 13,324 & 46,463 & 39,170 & 98,957 \\
\hline $\begin{array}{c}\text { General Surgery } \\
\text { admissions }\end{array}$ & 633 & 6,044 & 6,191 & 12,868 \\
\hline $\begin{array}{c}\text { Admissions with } \\
\text { Appendicitis as } \\
\text { provisional } \\
\text { diagnosis }\end{array}$ & 72 & 413 & 95 & 580 \\
\hline
\end{tabular}

Table 2: Age and Sex Distribution

\begin{tabular}{|c|c|c|c|c|c|}
\hline \multirow[t]{3}{*}{ Characteristic } & \multicolumn{4}{|c|}{ Appendicectomy } & \multirow[t]{3}{*}{ P Value } \\
\hline & \multicolumn{2}{|c|}{ Open } & \multicolumn{2}{|c|}{ Laparoscopic } & \\
\hline & No & $\%$ & No & $\%$ & \\
\hline Patient analyzed & 60 & 100 & 66 & 100 & - \\
\hline $\begin{array}{l}\text { Sex } \\
\text { Males } \\
\text { Females } \\
\end{array}$ & $\begin{array}{l}34 \\
26 \\
\end{array}$ & $\begin{array}{l}57 \\
43 \\
\end{array}$ & $\begin{array}{l}26 \\
40 \\
\end{array}$ & $\begin{array}{l}39 \\
61 \\
\end{array}$ & 0.08 (NS) \\
\hline $\begin{array}{l}\text { Age ( Years ) } \\
\text { Below } 30 \\
30-49 \\
50 \text { \& Above }\end{array}$ & $\begin{array}{l}43 \\
14 \\
3 \\
\end{array}$ & $\begin{array}{r}72 \\
23 \\
5\end{array}$ & $\begin{array}{r}46 \\
18 \\
2\end{array}$ & $\begin{array}{c}70 \\
27 \\
3\end{array}$ & \\
\hline Mean Age & 28 & & 27 & & $>0.2(\mathrm{NS})$ \\
\hline
\end{tabular}

NS - Not Statistically

Table 3: Presenting Complaints

\begin{tabular}{|l|l|l|l|l|c|}
\hline \multirow{3}{*}{ Complaint } & \multicolumn{2}{|l|}{ Appendicectomy } & \multirow{2}{*}{ P Value } \\
\cline { 2 - 5 } & Open (60 pts) & \multicolumn{2}{|l|}{ Laparoscopy (66 pts) } & \\
\cline { 2 - 5 } & No & $\%$ & No & $\%$ & \\
\hline Abdominal pain & 60 & 100 & 66 & 100 & - \\
\hline Vomiting & 55 & 92 & 63 & 95 & $0.06(\mathrm{NS})$ \\
\hline Fever & 53 & 88 & 64 & 97 & $0.09(\mathrm{NS})$ \\
\hline Loss of appetite & 40 & 67 & 59 & 89 & $<0.01(\mathrm{~S})$ \\
\hline
\end{tabular}

Table 4: Past History

\begin{tabular}{|l|c|c|c|c|c|}
\hline \multirow{2}{*}{ History of } & \multicolumn{2}{|l|}{ Appendicectomy } & \multirow{2}{*}{ P Value } \\
\cline { 2 - 5 } & Open (60 pts) & \multicolumn{2}{l|}{ Laparoscopy (66 pts) } & \\
\cline { 2 - 5 } & No & $\%$ & No & $\%$ & \\
\hline Diabetes Mellitus & 4 & 7 & 5 & 8 & $>0.2(\mathrm{NS})$ \\
\hline Heart disease & 1 & 2 & 0 & 0 & $>0.2(\mathrm{NS})$ \\
\hline Episodes of pain & 6 & 10 & 6 & 9 & $>0.2(\mathrm{NS})$ \\
\hline
\end{tabular}

Table 5: Habits

\begin{tabular}{|l|c|c|c|c|c|}
\hline \multirow{2}{*}{ Habits } & \multicolumn{2}{|l|}{ Appendicectomy } & \multirow{2}{*}{ P Value } \\
\cline { 2 - 5 } & Open (60 pts) & \multicolumn{2}{|l|}{ Laparoscopy (66 pts) } & \multirow{1}{*}{} \\
\cline { 2 - 5 } & No & $\%$ & No & $\%$ & \\
\hline Alcoholism & 4 & 7 & 3 & 5 & $>0.2(\mathrm{NS})$ \\
\hline Smoking & 8 & 13 & 2 & 3 & $0.05(\mathrm{~S})$ \\
\hline
\end{tabular}


Comparative Study Of Open Versus Laparoscopic Appendicectomy

\begin{tabular}{|l|l|l|l|l|l|}
\hline & & & & & \\
\hline Vegetarian & 12 & 20 & 14 & 21 & $>0.2(\mathrm{NS})$ \\
\hline
\end{tabular}

Table 6: Systemic Examination

\begin{tabular}{|c|c|c|c|c|c|}
\hline \multirow[t]{3}{*}{ Details of } & \multicolumn{4}{|c|}{ Appendicectomy } & \multirow[t]{3}{*}{ P Value } \\
\hline & \multicolumn{2}{|c|}{ Open (60 pts) } & \multicolumn{2}{|c|}{ Laparoscopy (66 pts) } & \\
\hline & No & $\%$ & No & $\%$ & \\
\hline $\begin{array}{l}\text { Build \& Nutrition } \\
\text { Good } \\
\text { Moderate } \\
\text { Poor }\end{array}$ & $\begin{array}{r}3 \\
55\end{array}$ & $\begin{array}{c}5 \\
92\end{array}$ & $\begin{array}{r}4 \\
61\end{array}$ & $\begin{array}{c}6 \\
92\end{array}$ & $>0.2(\mathrm{NS})$ \\
\hline $\begin{array}{l}\text { Anaemia } \\
\text { Negative }\end{array}$ & 60 & 100 & 66 & 100 & - \\
\hline $\begin{array}{l}\text { Lymph nodes } \\
\text { Negative }\end{array}$ & 60 & 100 & 66 & 100 & - \\
\hline $\begin{array}{l}\text { CVS } \\
\text { Normal }\end{array}$ & 59 & 98 & 66 & 100 & $0.05(\mathrm{~S})$ \\
\hline $\begin{array}{l}\mathrm{RS} \\
\text { Normal }\end{array}$ & 60 & 100 & 66 & 100 & - \\
\hline
\end{tabular}

Table 7: Local Examination

\begin{tabular}{|c|c|c|c|c|}
\hline \multirow[t]{3}{*}{ Details of } & \multicolumn{4}{|c|}{ Appendicectomy } \\
\hline & \multicolumn{2}{|c|}{ Open $(60$ pts $)$} & \multicolumn{2}{|c|}{ Laparoscopy (66 pts) } \\
\hline & No & $\%$ & No & $\%$ \\
\hline $\begin{array}{l}\text { RIF Tenderness } \\
\text { Yes }\end{array}$ & 60 & 100 & 66 & 100 \\
\hline $\begin{array}{l}\text { Abdominal mass } \\
\text { No }\end{array}$ & 60 & 100 & 66 & 100 \\
\hline
\end{tabular}

Table 8: Physical Examination

\begin{tabular}{|l|c|c|c|}
\hline \multirow{2}{*}{ Examination } & \multicolumn{2}{|c|}{ Appendicectomy } & \multirow{2}{*}{ P-Value } \\
\cline { 2 - 3 } & Open (60 pts) & Laparoscopy (66 pts) & \\
\hline $\begin{array}{l}\text { Blood Pressure } \\
(\mathrm{mm} \mathrm{Hg})\end{array}$ & $131 / 81$ & $133 / 86$ & $-(\mathrm{NS})$ \\
\hline Pulse (Per Min) & 87 & 84 & $0.07(\mathrm{NS})$ \\
\hline Temperature $\left({ }^{0} \mathrm{~F}\right)$ & 99.3 & 99.4 & $>0.2(\mathrm{NS})$ \\
\hline
\end{tabular}

Table 9: Abdominal Ultrasound Results

\begin{tabular}{|l|l|l|l|l|l|}
\hline \multirow{3}{*}{ Results } & \multicolumn{2}{|l|}{ Appendicectomy } & \multicolumn{2}{|l|}{ P Vaparoscopy $(66 \mathrm{pts})$} & \\
\cline { 2 - 5 } & Open (60 pts) & No & $\%$ & \\
\cline { 2 - 5 } & No & $\%$ & 66 & 100 & \multirow{2}{*}{$>0.2$ (NS) } \\
\hline Normal & 59 & 98 & 0 & 0 & \\
Abnormal & 1 & 2 & 0 & \\
\hline
\end{tabular}

Table 10: ASA Status

\begin{tabular}{|c|c|c|c|c|c|}
\hline \multirow[t]{3}{*}{ Details of } & \multicolumn{4}{|c|}{ Appendicectomy } & \multirow[t]{3}{*}{ P Value } \\
\hline & \multicolumn{2}{|c|}{ Open $(60 \mathrm{pts})$} & \multicolumn{2}{|c|}{ Laparoscopy (66 pts) } & \\
\hline & No & $\%$ & No & $\%$ & \\
\hline 1 & 57 & 95 & 62 & 64 & \\
\hline 2 & 2 & 3 & 4 & 6 & $>0.2(\mathrm{NS})$ \\
\hline 3 & 1 & 2 & 0 & 0 & \\
\hline Median Score & \multicolumn{2}{|c|}{1} & \multicolumn{2}{|c|}{1} & \\
\hline
\end{tabular}

Table 11: Position of the Appendix

\begin{tabular}{|l|c|c|c|c|c|}
\hline \multirow{3}{*}{ Position } & \multicolumn{2}{|l|}{ Appendicectomy } & \multicolumn{2}{|c|}{ P Vaparoscopy (66 pts) } & \\
\cline { 2 - 5 } & Open (60 pts) & $\%$ & No & $\%$ & \\
\cline { 2 - 5 } & No & 95 & 66 & 100 & \multirow{3}{*}{0.1 (NS) } \\
\hline Retrocecal & 57 & 5 & 0 & 0 & \\
Ileal & 3 & 0 & 0 & 0 & \\
Pelvic & 0 & & & \\
\hline
\end{tabular}

Table 12: Result of open and laparoscopic Appendicectomy

\begin{tabular}{|l|l|l|l|l|l|}
\hline \multirow{2}{*}{ Details } & \multicolumn{2}{|l|}{ Appendicectomy } & \multirow{2}{*}{ P Value } \\
\cline { 2 - 5 } & Open (60 pts) & \multicolumn{2}{l|}{ Laparoscopy (66 pts) } & \\
\cline { 2 - 5 } & No & $\%$ & No & $\%$ & \\
\hline $\begin{array}{l}\text { Blood loss } \\
\text { Below } 50 \mathrm{ml}\end{array}$ & 56 & 93 & 65 & 98 & 0.2 (NS) \\
\hline
\end{tabular}




\begin{tabular}{|l|c|l|l|l|l|}
\hline $50-100 \mathrm{ml}$ & 4 & 7 & 1 & 2 & \\
\hline $\begin{array}{l}\text { Adj. Organ Injury No } \\
\begin{array}{l}\text { Duration of surgery } \\
\text { Operation (min) }\end{array}\end{array}$ & 60 & 100 & 65 & 98 & $>0.2$ (NS) \\
\cline { 2 - 5 } & $\begin{array}{c}64 \pm 30 \\
(15 \text { to150) }\end{array}$ & $\begin{array}{c}73 \pm 26 \\
(30 \text { to } 135)\end{array}$ & $\begin{array}{c}0.07 \\
(\mathrm{NS})\end{array}$ \\
\hline
\end{tabular}

Mean \pm SD; Note: Figure in bracket denote the range.

Table 13

\begin{tabular}{|c|c|c|c|c|c|}
\hline \multirow[t]{3}{*}{ Details of } & \multicolumn{4}{|c|}{ Appendicectomy } & \multirow[t]{3}{*}{ P Value } \\
\hline & \multicolumn{2}{|c|}{ Open (60 pts) } & \multicolumn{2}{|c|}{ Laparoscopy (66 pts) } & \\
\hline & No & $\%$ & No & $\%$ & \\
\hline $\begin{array}{l}\text { Co-existing } \\
\text { pathology } \\
\text { negative }\end{array}$ & 60 & $\begin{array}{l}1 \\
0 \\
0\end{array}$ & 63 & 95 & $0.2(\mathrm{NS})$ \\
\hline $\begin{array}{l}\text { HPE } \\
\text { Acute } \\
\text { Appendicitis }\end{array}$ & $\begin{array}{l}48 \\
12\end{array}$ & $\begin{array}{l}8 \\
0 \\
2 \\
0\end{array}$ & $\begin{array}{l}47 \\
19\end{array}$ & $\begin{array}{l}71 \\
29\end{array}$ & $\begin{array}{l}>0.2 \\
\text { (NS) }\end{array}$ \\
\hline
\end{tabular}

Table 14: Wound infection and Post-Operative medication

\begin{tabular}{|l|l|l|l|}
\hline \multirow{2}{*}{ Details } & \multicolumn{2}{|c|}{ Appendicectomy } & \multirow{2}{*}{ P-Value } \\
\cline { 2 - 3 } & Open (60 Pts) & Laparoscopy (66 Pts) & 0.02 (S) \\
\hline Wound infection rate & $8 \%$ & $0 \%$ & $<0.001$ (S) \\
\hline Antibiotics used & $2 \pm 0.8$ & $1.5 \pm 0.5$ & \\
Parenteral (days) & $(1$ to 4$)$ & $(1$ to 2$)$ & \\
Oral (days) & $2 \pm 0.6$ & $3 \pm 0$ & \\
& $(1$ to 4$)$ & $(3)$ & \\
\hline Analgesics used & $2+0.7$ & $2+0$ & \\
Parenteral (days) & $(1$ to 4$)$ & $(2)$ & \\
Oral (days) & $2+0.5$ & $1+0$ & \\
& $(1$ to 3$)$ & $(1)$ & \\
\hline
\end{tabular}

Table 15: Post-Operative course

\begin{tabular}{|l|l|c|c|}
\hline \multirow{2}{*}{ Details } & \multicolumn{2}{|c|}{ Appendicectomy } & P-Value \\
\cline { 2 - 4 } & Open (60 Pts) & Laparoscopy (66 Pts) & \\
\hline $\begin{array}{l}\text { Time to resumption of oral feeds } \\
\text { (days) }\end{array}$ & $\begin{array}{c}1.6 \pm 0.8 \\
(1 \text { to } 4)\end{array}$ & $\begin{array}{c}1.1 \pm 0.3 \\
(1 \text { to } 2)\end{array}$ & $<0.001$ (S) \\
\hline $\begin{array}{l}\text { Duration of hospital stay } \\
\text { (days) }\end{array}$ & $\begin{array}{l}3 \pm 1.5 \\
(1 \text { to } 8)\end{array}$ & $\begin{array}{l}2 \pm 0.6 \\
(1 \text { to } 4)\end{array}$ & $<0.001$ (S) \\
\hline $\begin{array}{l}\text { Time to retum to normal duties } \\
\text { (days) }\end{array}$ & & & \\
& & & \\
\hline
\end{tabular}

Table16: Patients perception about cosmetic end result.

\begin{tabular}{|l|c|c|c|c|c|}
\hline \multirow{2}{*}{ Details of } & \multicolumn{2}{|l|}{ Appendicectomy } & \multirow{2}{*}{ P Value } \\
\cline { 2 - 5 } & \multicolumn{2}{|l|}{ Open (60 pts) } & No & \\
\cline { 2 - 5 } & No & $\%$ & 0 & 0 & \\
\hline Unacceptable & 3 & 5 & 0 & 0 & \\
O.K. & 4 & 7 & 1 & 2 & $<0.001(\mathrm{~S})$ \\
Acceptable & 34 & 57 & 6 & 9 & \\
Good & 18 & 30 & 59 & 89 & \\
Excellent & 1 & 2 & & \\
\hline
\end{tabular}

